\title{
Using e-Quiz to Promote Arts Students' Self-Regulated Learning
}

\author{
Estri Oktarena Ikrarini, Hanandyo Dardjito \\ \{oktarena@ustjogja.ac.id ${ }^{1}$, hanandyo@ustjogja.ac.id² $\}$ \\ Faculty of Teachers Trainings and Education, Universitas Sarjanawiyata Tamansiswa, Yogyakarta, \\ Indonesia ${ }^{1,2}$
}

\begin{abstract}
The forthcoming 4.0 industrial era brings the concept of Internet of Things (IoT) to every aspect of the society's life, including education. This concept requires a fundamental change in the way the teaching and learning process should be conducted as both teachers and students are wirelessly connected. Using e-quiz as a part of classroom activities can be an alternative way, as traditional students are not actively engaged in virtual classroom. This study shows that students are encouraged to work independently by choosing time and place that are most appropriate to them, and also by selecting appropriate strategies while dealing with the e-quiz. They also showed some improvements in their metacognitive skills and time management.
\end{abstract}

Keywords: e-quiz, self-regulated, learning, student

\section{Introduction}

The approach of 4.0 industrial era brings significant changes in many aspects of our lives. It also affects education as the use of the Internet has made learning possible to be accessed by anyone, anytime, and anywhere. This brings both benefits and challenges; it is easier for students to access learning materials and to conduct their learning activities from any places, so that they can choose any learning institutions appropriate to their needs. However, the practice of online learning also requires teachers to reconstruct the teaching and learning processes to suit the needs of the students, and it often becomes a challenge for them.

Many studies indicate that online learning is considered more effective in several areas, such as organizations, students' achievement, and learning process as in [1] [2] [3]. In this spirit, the learning process in universities also undergoes a paradigm shift in which online learning becomes an integrated part of higher institutions. Both teachers and students need to adapt to the current trend in education, and change the way their teaching and learning processes are conducted.

English language is one of obligatory subjects taught in Arts Education Program, Faculty of Teachers Training and Education, Universitas Sarjanawiyata Tamansiswa. This subject is designed for 1st semester students. In the odd semester academic year of 2018/2019, there were 160 students taking the General English class; divided into four classes. As the university is preparing for the information technology era, the class is designed to be both traditional and digital. From fourteen class meetings, four meetings were designed to be online class meetings; means that all activities were conducted online. However, the offline class (the traditional ones) also required students to work on online quiz based on materials that have been discussed in the 
class. The use of e-quiz was to help the lecturer control the progress of each student. As they did their online tasks, it was easier for the lecturer to record the works of the students.

To integrate the traditional and online classes, the lecturer uploaded all class materials on Edmodo. Edmodo is an online learning platform that connects teachers and students, even parents in one application. Students were, then, asked to download the materials by themselves and brought them to the classroom. In the classroom, students activities covered both individual and class discussions to deal with the reading texts and exercises. On the following day, an equiz was uploaded on Edmodo based on the materials that had been discussed in the classroom. Students had 60 minutes to work on each quiz covering 20 to 30 questions. When the class meetings were designed to be fully virtual, class activities were conducted online: from uploading the materials, online discussions, and working on e-quiz. Students might also be asked to upload their free writing project or translation works.

Regarding to the learning of English language by those Arts students, there are some problems arise in this area. First, their low-level of English gives a great challenge for the students in comprehending the reading texts or class materials. The students also showed distinctive characteristics of being Arts students, e.g. liberal and forthright. These characteristics could be identified during the observation, and constantly shown by most students during the teaching-learning process. Thus, at the beginning, the idea of having some quizzes in the English class received a kind of resistance from most students. Dealing with these problems, it was necessary for the teacher to encourage the students to develop their self-regulated skills as it is in accordance with their very nature of being liberal. Therefore, this study tries to address on how to develop the Arts students' self-regulated skills by using e-quiz.

\section{Self-Regulated Learning}

The term of self-regulated learning first appeared in 1980's. In its development, students can be defined as being self-regulated when they are, in their own learning processes, becoming participants who are metacognitively, motivationally, and behaviorally active [4]. When students are metacognitively active, they are aware of having both academic strengths and weaknesses, what resources they have to fulfill their academic tasks, and how to be engaged in doing the tasks to optimize their achievements. As for being motivated, it means that students believe that they have intrinsic motivation to help them cope with the tasks by using strategies effectively. While dealing with the tasks, students also opted for appropriate tactics that could help them to work in certain situation [5] [6]. The model of Zimmerman's SRL consists of three phases, i.e. forethought, performance control, and self-reflection [7]. In the forethought phase, there are two main classes: task analysis and self-motivation. Two main classes existed in the performance phase are self-control and self-observation. In the last phase, self-reflection, there are two main classes: self-judgment and self-reaction.

In this study, the students' strategies of SRL are taken from 15 classes of self-regulated behavior proposed by Zimmerman and Ponz [8]. Among them, 14 classes are self-initiated strategies by students, and 1 class other can be categorized as non-self-regulated behavior. This model is used in this study since its categories are clearly formulated and easy to reveal by using interview technique. 
Table 1. Lists of SRL Strategies Categories as proposed by Zimmerman and Pons.

\begin{tabular}{|c|c|c|}
\hline \multicolumn{2}{|c|}{$\begin{array}{c}\text { Categories of Self-Regulated } \\
\text { Strategies }\end{array}$} & \multirow{2}{*}{$\begin{array}{l}\text { Definitions } \\
\begin{array}{l}\text { Student-initiated evaluations of the quality or progress of their } \\
\text { work }\end{array}\end{array}$} \\
\hline 1. & Self-evaluation & \\
\hline 2. & $\begin{array}{l}\text { Organizing and } \\
\text { transforming }\end{array}$ & $\begin{array}{l}\text { Student-initiated overt or covert rearrangement of instructional } \\
\text { materials to improve learning }\end{array}$ \\
\hline 3. & $\begin{array}{l}\text { Goal-setting and } \\
\text { planning }\end{array}$ & $\begin{array}{l}\text { Student setting of educational goals or subgoals and planning } \\
\text { for sequencing, timing, completing activities related to those } \\
\text { goals }\end{array}$ \\
\hline 4. & Seeking information & $\begin{array}{l}\text { Student-initiated efforts to secure further task information from } \\
\text { nonsocial sources when undertaking an assignment }\end{array}$ \\
\hline 5. & $\begin{array}{l}\text { Keeping records and } \\
\text { monitoring }\end{array}$ & Student-initiated efforts to record events and results \\
\hline 6. & $\begin{array}{l}\text { Environmental } \\
\text { structuring }\end{array}$ & $\begin{array}{l}\text { Student-initiated efforts to select or arrange the physical setting } \\
\text { to make learning easier }\end{array}$ \\
\hline 7. & Self-consequences & $\begin{array}{l}\text { Student arrangement or imagination of rewards or punishment } \\
\text { for success or failure }\end{array}$ \\
\hline 8. & $\begin{array}{l}\text { Rehearsing and } \\
\text { memorizing }\end{array}$ & $\begin{array}{l}\text { Student-initiated efforts to memorize material by overt or covert } \\
\text { practice }\end{array}$ \\
\hline & Seeking social assistance & $\begin{array}{l}\text { Student-initiated efforts to solicit help from (9) peers, (10) } \\
\text { teachers, and (11) adults }\end{array}$ \\
\hline & Reviewing records & $\begin{array}{l}\text { Student-initiated efforts to reread (12) texts, (13) notes, or (14) } \\
\text { textbooks to prepare class or further testing }\end{array}$ \\
\hline 15. & Other & $\begin{array}{l}\text { Learning behavior that is initiated by other persons, e.g. } \\
\text { teachers, parents, and all unclear verbal responses }\end{array}$ \\
\hline
\end{tabular}

Many researches also noted how online learning promote students' self-regulated learning [9] [10] and vice versa. By conducting online learning, students have their freedom to choose their own time, resources, and strategies to do the tasks since they can work from any places. Within the concept of SRL, students are required to be active learners by taking responsibilities of their own learning process. Thus, by employing SRL skills, students are considered to succeed in online learning. Some studies also suggest the needs of SRL skills in online learning process since these skills can contribute to the students' academic success. It is highly important for students who attend online classes to develop SRL skills and strategies because they need to rely on themselves in completing their academic tasks.

\section{Method Of Research}

This study was a qualitative research. The use of qualitative methods for investigating students' self-regulated learning is also encouraged by Perry in [11] as this can disclose multiple areas of SRL. Data for the research were collected by using documentation, interview, and observation. In validating the data, different methods and perspective were used in doing the analysis. The documentation covered recording some information taken from Edmodo application based on the tasks, assignments, and quizzes taken by the students. The structured interview was conducted to get data related to strategies chosen by the students; while the observation was done to collect data about students' performances in the class. The participants 
of this study were 160 students from Arts Education Program of FKIP UST. The students took English language class in the academic year 2018/2019.

\section{Result}

As Arts students in FKIP UST is a non-English speaking class, most students showed lowlevel of their English. Students could even barely understood English instructions. Thus, in the classroom, the lecturer usually used bilingual instructions: English and Indonesian languages. This became a challenge for the teacher to improve their language skill, especially to deal with the reading texts and arts vocabulary. Students need to master the arts vocabulary since they will need the words to present their artworks using English.

Based on the observation, students showed some good progresses in working with the equizzes. The numbers of students who did the e-quizzes gradually increased since the first quiz uploaded. Every quiz uploaded was set to have a due date. Students who did not do the quiz during the quiz period could not access the quiz after the due date. They should also finish answering the quiz once they started it because they could not open the quiz anymore after 60 minutes.

In the first quiz, almost half numbers of students had problems working with the quiz due to several reasons. They were not aware of the time limit so that they could not finish answering all the questions. Students also made some mistakes by leaving the quiz before it ended, thus they could not re-enter the quiz. Others failed doing the quiz since they did not prepare the materials needed to work on the quiz. Some other students had difficulties due to some technical problems, such as with their internet connections or login problems to Edmodo application. In the subsequent quizzes, students showed better performance in completing the task. The numbers of students who completed the quizzes also increased significantly.

Based on the interview conducted to reveal the students SRL behaviors while working on the e-quizzes, there were 12 strategies out of 15 classes of SRL in the Self-Regulated Learning Interview Schedule [5] [8]. Those strategies are: self-evaluation; organizing and transforming; goal setting and planning; seeking information; keeping records and monitoring; environmental structuring; self-consequences; seeking help from peers; seeking help from teachers; reviewing notes and textbooks; and other. Among those strategies, students also revealed that environmental structuring, goal setting and planning, seeking information from nonsocial resources, and seeking help from peers were the most effective strategies in dealing with the equizzes.

\section{Discussion}

Arts students of FKIP UST employed several strategies while dealing with the e-quizzes of English class. The strategy of environmental structuring is important for the students as they needed to focus on completing the task. Choosing appropriate place and time to work on the quiz holds important role in their performance. They chose a place with stable internet connection, like campus or café with free wireless internet connection. As students also installed Edmodo application on their smartphone, it is also easier for them to check new tasks, assignments, or quizzes posted for their class. While some students preferred to work on the equizzes after school, others chose to work during the school time, especially when they wanted 
to use the campus facility, like the wifi. There are some places that students most likely chose to do the quizzes: at home or boarding house, campus, and café. The students also found that it was helpful to install Edmodo on their phone, so they can also check any new tasks or quizzes and their progress once the tasks they submitted have been graded by the lecturer. By doing this, students could easily deal with the e-quiz relating to time and place management. Thus, students showed their awareness of avoiding any technical problems due to internet connection, for example.

Students also showed good efforts in dealing with goal setting and planning. They fully understood about the due time and its consequences that they might lose some points from the uncompleted quizzes. They are aware that it might bring them to fail the class. Thus, they usually planned some activities prior to the e-quiz completion; such as, translating the reading texts from English into Indonesian language at least one day before doing the quiz. Students reviewed their class or quiz materials by conducting covert rearrangement [8], i.e. translating the reading texts into Indonesian, and also with the exercises. By having the texts in Indonesian language, it was easier for them to understand the texts and to complete the tasks. The e-quiz requires them to apply this strategy since it can help them cope with the quiz completion, partly due to the time limit.

When they had difficulties in dealing with the reading texts or class materials, students tended to seek helps from their friends or classmates. They could ask their friends for any new tasks or assignments, or even for discussing the class materials. Since the e-quiz is designed as an individual task, students need to work independently. However, they also revealed that they sometimes relied for their friends' assistance while working on the e-quiz, so they could ask for any difficult vocabulary or materials they did not understand.

Seeking help from teachers was done by some students who got some problems with their Edmodo applications. At the beginning of the class, students did not show any enthusiasm for doing online tasks because they were more familiar with traditional class settings. As the consequence, when the first e-quiz was posted on Edmodo, only half of the students did the quiz. Others asked for offline ones, though their request was not granted. However, only a small number of students who asked for the lecturer's help when they had problems with the class materials, especially with the quiz completion.

Seeking social assistance holds greater impact on the students' performance as indicated during the interview process. Although they needed to consult their class materials to complete the e-quiz, most of them stated that they rarely reread their previous notes or textbooks. This surprising fact appeared when some students revealed that they tended to rely on their friends' help rather than trying to seek their own answers by reviewing their notes or textbooks. Students reviewed their notes mostly in the classroom while discussing the materials with the lecturer.

While dealing with quiz materials, students also initiated efforts to find further information from nonsocial sources, especially the Internet. The Internet nowadays provides many facilities regarding language assistance, such as Google translate and online dictionary. The existence of the Internet also affects the choice of nonsocial source; students no longer consider library as a source of information, they turn to the Internet for finding any answers to their problems or questions, since they are able to do so. The e-quizzes posted on the Edmodo application also open opportunities for students to check the Internet while they were having some problems in doing the task.

Though most students showed their efforts in keeping records by taking notes of difficult vocabulary or words related to arts studies, this strategy was less familiar for the students while taking the e-quizzes. Applying self-consequences strategy was also familiar for those Arts students of FKIP. They are fully aware of the consequence of being absent working on the e- 
quizzes; they would fail the class. Even though, all students indicated that they never gave themselves any rewards for their success in doing the e-quizzes. They tend to view the e-quiz as their obligatory task, thus when they succeeded in doing it, it was merely seen as part of their assignment of taking English class. It is unnecessary to have any rewards, but it is important for them not to fail the quizzes if they want to pass the class. This view may also supports the Other strategy, i.e. doing the quizzes because the lecturer asked them to do so.

Related to the first component of SRL, i.e. the metacognitive strategies in planning, monitoring, and modifying the students' cognition [12] [13], the efforts conducted by the Arts students showed how the e-quizzes could promote their SRL skills improvement. To complete the e-quizzes, students could not rely on the explanation given by the lecturer or to have the quiz discussed in the classroom. Though the lecturer might give some comments during the grading process, this step was done after they finished working with the quiz. By making the quizzes online, the lecturer also encouraged the students to have a plan and opt for some appropriate strategies so that they could answer all the questions on the e-quizzes. The plan could include translating the texts, seeking for their friends help to discuss the materials, or arranging times and places best suited to their needs. The use of Edmodo also facilitates the students to monitor their progress in the English class, especially with the task completion. When having some problems, the students may need to modify their strategies or alter to other strategies in SRL. Different cognitive strategies, such as discussing the quiz materials with their friends could also contribut to higher achievement level. These efforts of task management and academic tasks become key components in the students' performance.

Nevertheless, those efforts in the metacognitive areas must also be supported by internal motivation. Students should be motivated to use the SRL strategies [12]. The motivation could appear from the students' belief of their own capability in performing the task, i.e. the e-quizzes. This study also reveals that most of the Arts students of FKIP UST felt they were capable of doing the e-quizzes by applying different SRL strategies. In general, it can be concluded that students who believed that they were capable in doing the e-quizzes, applying more cognitive strategies performed better than those who felt being unable.

It is important to note that those values are highly related to the application of SRL strategies and being self-regulated. Students who think that they are capable of doing the equizzes because they think that the quiz can help them learn the materials better will be more self-regulated than those who think that the e-quizzes are only an obligatory task. The former will develop their SRL skill in greater degree as they are cognitively engaged with their own learning process. This finding is similar to those of Pintrich and DeGroot [12] who stated that students who were motivated in their learning process tend to be more self-regulating and becoming persistence in completing their academic task.

\section{Conclusion}

To summarize, the use of e-quizzes has encouraged Arts students of FKIP UST to develop their SRL skills. Students need to deal with appropriate strategies that suit their needs and situation. However, it is also important for the students to have internal motivation that the equizzes help them understand the materials better. Students need to be actively engaged in their learning process, so that they could perform better and complete all academic tasks. This can be achieved if the students feel that they need English language to improve their language skill and to seek for new opportunities to exhibit their artworks. Therefore, teachers need also to supply 
them with the materials that best suit to their need, i.e. materials that they find useful to support their creative works. Students also needs to be persistently encouraged to make independent choices regarding academic task completion.

When the students are actively involved in self-regulated environment built in the classroom, it is believed that their performance may better improved. This environment also ensures that students can develop their belief that they are capable of completing any academic tasks, and therefore, they are also capable of choosing appropriate SRL strategies to deal with different tasks or situation. By conducting e-quiz or online learning, teachers can also assure that every student is involved in the learning process by their own pace. In this way, teachers can also promote students' confidence in learning because they take the greatest responsibility of their learning progress. However, the e-quiz is not without any challenges, as students may fail in completing the tasks due to some factors, such as technical problems, lacks of selfregulation, and others. Though some strategies can be applied by teachers in dealing with this situation, e.g. by promoting self-regulated skills to the students during the running semester to continuously remind them about the goals they need to achieve. The e-quizzes posted on regular interval can also help students stick to their plans - the plans that have been set in the forethought phase - to succeed in their academic achievement.

Acknowledgments. This study is supported by the English Education Program, Faculty of Teachers Training and Education (FKIP), Universitas Sarjanawiyata Tamansiswa.

\section{References}

[1] M. E. Wang, "Students' characteristics, self-regulated learning, technology selfefficcacy, and course outcomes in web-based courses .," 2010.

[2] and J. E. A. R. Burgess, Jennifer R. D., "The effectiveness of distance learning initiatives in organizations," J. Vocat. Behav., vol. 63, pp. 289-303, 2003.

[3] and M. B. Means, Barbara., Y. Toyama, R. Murphy, "Effectiveness of online and blended learning," Teach. Coll. Rec., vol. 115, pp. 1-47, 2013.

[4] and D. H. S. Zimmerman, Barry J., Self-Regulated Learning and Academic Achievement: Theory, Research, and Practice. Books. 1989.

[5] and N. E. P. Winne, P.H., "Measuring Self-Regulated Learning, Handbook of SelfRegulation.," 2000, pp. 531-566.

[6] B. J. Zimmerman, "Self-Regulated Learning and Academic Achievement: An Overview, Educational Psychology," vol. 25, pp. 3-17, 1990.

[7] B. J. Zimmerman, "Becoming a Self-Regulated. Theory into Practice," vol. 41, p. . 64 70, 2002.

[8] and M. M. P. Zimmerman, Barry J., "Development of a Structured Interview for Assessing Student Use of Self-Regulated Learning Strategies,” pp. 614 - 628, 1986.

[9] and W. G. Santoso, Harry B., "Self-regulated learning skills and online activities between higher and lower performers on a Web intensive undergraduate engineering course hydraulic structures view project distance education-online education-learning styles view project," J. Educ., pp. 1 - 33, 2014.

[10]J. B. and W. J. I. Wandler, "Promoting College Student Self-Regulation in Online Learning Environments," Online Learn., vol. 21, pp. 1-16, 2017.

[11]N. E. Perry, "Introduction: Using Qualitative Methods to Enrich Understandings of SelfRegulated Learning," Educ. Psychol., vol. 37, pp. 1-3, 2002. 
[12] and E. V. D. G. Pintrich, Paul R., "Motivational and Self-Regulated Learning Components of Classroom Academic Performance.," J. Educ. Psychol., vol. 82, pp. 33 - 40, 1990.

[13]B. J. A. Zimmerman, "Social Cognitive View of Self-Regulated Academic," J. Educ. Psychol., vol. 81, pp. $1-23,1989$. 